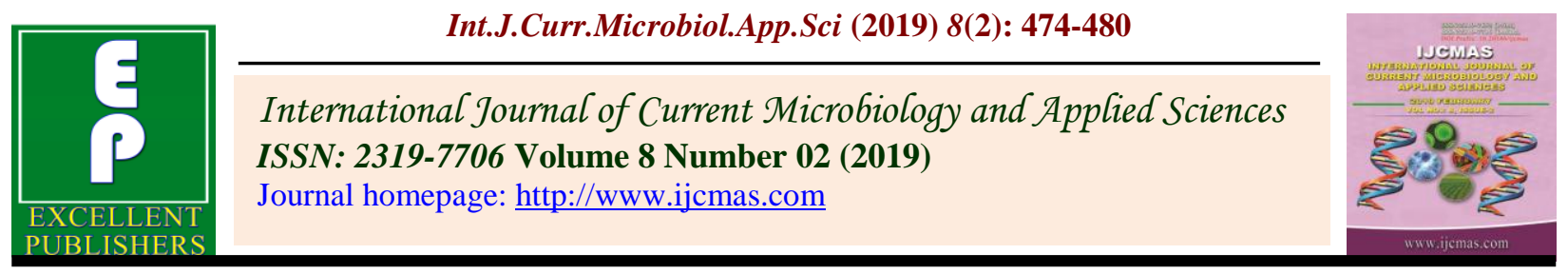

Original Research Article

https://doi.org/10.20546/ijcmas.2019.802.053

\title{
A Study on Adolescent Girl School Dropout in Mahabubnagar District of Telangana State, India
}

\author{
B. Sathwika* and R. Geetha Reddy
}

Department of Home Science Extension and Communication Management, Hyderabad,
Professor Jayashankar Telangana State Agricultural University, Telangana, India

*Corresponding author

\begin{tabular}{|c|c|}
\hline & A B S T R A C T \\
\hline Keywords & \multirow{4}{*}{$\begin{array}{l}\text { Education should be the dynamic form of philosophy of any nation. India desired to adopt } \\
\text { a socialistic way of life. As education is the only means to bring about the desired social } \\
\text { change, a vast amount of money has been spent on education by the state. The present } \\
\text { study was undertaken in } 8 \text { villages of Midjil mandal in Mahbubnagar district, Telangana } \\
\text { state. Though the school education department succeeded in increasing the enrolment ratio } \\
\text { in Mahbubnagar which is the most backward district in the state, it still continues to } \\
\text { witness the highest dropout rate. } 60 \text { school dropouts were selected for the study. Interview } \\
\text { method and self-developed questionnaire was used for data collection. The selection of the } \\
\text { participants followed purposive sampling method. Ex post facto research design was used } \\
\text { for the study. The findings of the study and conclusions confirm that personal reasons, } \\
\text { peer group influence and family environment are all related to school dropout. }\end{array}$} \\
\hline $\begin{array}{l}\text { Adolescent, Ex- } \\
\text { post facto, School } \\
\text { dropout }\end{array}$ & \\
\hline Artic & \\
\hline $\begin{array}{l}\text { Accepted: } \\
\text { 07 January } 2019 \\
\text { Available Online: } \\
\text { 10 February } 2019\end{array}$ & \\
\hline
\end{tabular}

\section{Introduction}

Education in India, is divided into are primary, secondary and higher education. In order to monitor the implementation of educational process, the governments have created organizational structure and facilitated with whatever material required for the purpose of all three stages or form of education. Primary education plays a vital role in it serves entry into the whole formal educational basis. The one who successfully passes through this stage would get into secondary and then higher education. For this reason, every society lay emphasis on primary education where it becomes the responsibility of parents, neighborhood, community, teacher, leadership and other to see to it that every child in put into school at right time for the right purpose. But unfortunately, this does not happen in case of several children for which the reasons are variety.

A student who withdraws before completing a course of instruction is considered as a dropout (Baharul Islam Laskar, 2017). Dropout rate is the percentage of students who drop out from a given grade or cycle or level of education in a given school year (GoI, 2014). According to the Oxford Advanced Learner's Dictionary dropout refers to a person who leaves school or college before they have finished their studies. India stands at 111 th position at the worldwide literacy 
rate. According to the Census of India 2011, $40 \%$ of the population did not finish their elementary education (Census, 2011a). School dropout rate amongst adolescent girls in India was as high as 63.5\% (MoSPI, 2012).

According to the ministry of human resource development (MHRD), 62.1 million) children are out of school in India. The 2011 Census estimated the figure at 84 million-nearly $20 \%$ of the age group covered under the Right to Education (RTE) Act. At this stage, traditional gender norms push girls into helping with household chores and sibling care, leading to irregular attendance that eventually results in dropouts. Early marriage, lack of safety in schools and low aspirations related to girls' education also lead to them dropping out.

Additional problems arise when the girl reaches secondary education. As the recent Annual Survey of Education Report (Aser, 2017) findings suggest, while on average the difference between enrolment levels of boys and girls at age 14 are declining, by 18, when the state doesn't enforce compulsory education through the RTE Act, $32 \%$ girls are not enrolled-compared to $28 \%$ boys. Bridging mechanisms for out-of-school children exist at the elementary stage, but are absent for secondary education. Hence girls find it difficult to re-enter education once they have dropped out. The number of schools also decreases sharply beyond upper primary. In 2015-16, for every 100 elementary schools (classes I to VIII) in rural India, there were 14 offering secondary (classes IX-X) and only six offering higher secondary grades (classes XI-XII). It has not helped that so many secondary schools are privately-owned, feecharging schools. At the elementary level, only $5 \%$ listed in the official statistics are private unaided schools while $40 \%$ schools offering secondary or higher secondary grades are private, unaided institutions. This stacks the odds against girls' education and leads to drop outs. It is critical to have a mechanism to identify girls at risk of dropping out and implement mechanisms to bring those that have dropped out back into school. The new definition of a dropout, 30 days of continuous unexcused absence, is a start, but would be inadequate; more regular touch points are needed to create timely corrective measures to ensure timely regular attendance.

Baharul islam laskar et al., (2017) studied 9 villages of Niuland Block under Dimapur district, Nagaland among the local tribal communities. Considering the negative impact of the phenomena it was found appropriate to explore the various factors such as family environment, personal characteristics and school environment related to early school dropout.

Ravi prakash et al., (2017) found that school dropouts were associated with economic factors (house hold poverty), social beliefs and practices (girl child marriage; value of girl child education) and school related factors (poor quality of learning at school; bullying harassing school environment).

Deepak Kumar Dey (2016) identified parent's attitude towards learning (PATL), parent's involvement (PI), parent-teacher relationships (PTR), and parent's attitude towards school environment (PATSENV) as key factors associated to school dropouts

Santosh Sangwan et al., (2016) revealed that majority of the respondents who were school drop outs belonged to lower middle category of socio-economic status and nearly fifty percent had showed average and above average interest in household work. Majority of respondents had low level of interest in artistic, agriculture, persuasive, scientific, executive and constructive type of vocations. Regarding the cohesion, expressiveness and 
conflict in the family, majority of respondents perceived average level of family environment. Equal percentage of respondents felt that degree of importance of clear organization structure in planning family activities and responsibilities is average and high.

Latif et al., (2015) found the reasons of dropouts in Pakistan and more importantly comparative analysis of the causes of student's dropouts globally. Financial problems, parents' unwillingness, distance and lack of basic facilities, bad quality of the education, inadequate school environment and building, overloaded class rooms, improper languages of teaching, carelessness of teachers and security problem in girl's school are found as major causes of student dropouts in different countries.

To study the profile characteristics of rural adolescent girls.

To analyze the reasons for rural adolescent girl school dropouts.

To know the awareness and utilization of ongoing educational programs to girl.

\section{Materials and Methods}

Based upon the nature of the research problem and objectives of the present study Ex post facto research design was opted for the study. The mahabubnagar district of Telangana state was purposively selected for the present study. In this study, samples comprising of 60 school dropout girls. Interview schedule and self-developed questionnaire developed by the investigator for the study which includes general profile of the adolescent school dropout, reasons for rural adolescent girl school dropouts, awareness and utilization of ongoing educational programs to girls. The scale has two major areas which consists six sub areas, reasons for dropout based on her personal issues, respondent peer group influence, teacher-student relationship, nature of school curriculum and its influence on decision to dropout, school physical environment and its influence on dropout, family environment i.e. 5 statements in reasons for dropout based on her personal issues, respondent peer group influence, nature of school curriculum and its influence on decision to dropout, school physical environment and its influence on dropout these four areas and 7 statements in teacher-student relationship, area 19 statements in family environment area. All statements are of negative manner. 1mark to yes statement, 2 marks to no statement, responses were assigned. For third objective 2 marks to yes statement and 1 mark to no statement was given. The sum of marks is obtained for the entire scale.

\section{Results and Discussion}

From the table 1, it is indicated more than half $63 \%$ of the respondent girls belonged to middle adolescence and $37 \%$ of them belonged to early adolescence. Majority $(60 \%)$ of the respondents dropped out when their education was in secondary level followed by $40 \%$ in upper primary level. As much as $67 \%$ of the respondent's families is 'nuclear' and 33\% are joint families. It can be noted that $93 \%$ of the respondent's father's occupation was 'Agriculture', 5\% are labourers and remaining (2\%) are drivers. Majority $(95 \%)$ of the respondent mother's occupation was 'Agriculture' followed by 5\% laborers and (2\%) wardenship. Nearly $95 \%$ of the respondent fathers are 'illiterates' followed by $3 \%$ have completed their 'primary education' and $2 \%$ have completed their 'middle school education'. Nearly $97 \%$ of the respondent's mothers are 'illiterates', and $3 \%$ of them have 'completed their primary education. $78 \%$ of adolescents belonged to 'ST category', followed by $10 \%$ are 'Schedule Caste' and $12 \%$ belonged to 'Backward Classes. 
From the table 2, the percentages of girls who are exposed to television are 53\% watch daily, $13 \%$ watch occasionally and $33 \%$ 'never' watches. When it comes to exposure towards mobile phones, $80 \%$ use daily, $7 \%$ occasionally and $13 \%$ never uses. Internet and Newspaper exposure was $0 \%$ that means they were never exposed to internet and newspapers.

Table.1 General profile of the respondents

\begin{tabular}{|c|c|c|c|}
\hline \multirow[t]{2}{*}{ S.No } & \multirow[t]{2}{*}{ Variable } & \multicolumn{2}{|c|}{ Respondents $(\mathrm{N}=60)$} \\
\hline & & $\mathbf{N}$ & $\%$ \\
\hline \multirow[t]{3}{*}{1} & \multicolumn{3}{|l|}{ Age } \\
\hline & $12-14$ & 22 & 37 \\
\hline & $15-17$ & 38 & 63 \\
\hline \multirow[t]{3}{*}{2} & \multicolumn{3}{|l|}{ Education } \\
\hline & $5^{\text {th }}-7^{\text {th }}$ standard & 24 & 40 \\
\hline & $8^{\text {th }}-10^{\text {th }}$ standard & 36 & 60 \\
\hline \multirow[t]{3}{*}{3} & \multicolumn{3}{|c|}{ Type of the family } \\
\hline & Joint Family & 20 & 33 \\
\hline & Nuclear family & 40 & 67 \\
\hline \multirow[t]{4}{*}{4} & \multicolumn{3}{|c|}{ Father's Occupation } \\
\hline & Agriculture & 56 & 93 \\
\hline & Wage labourer & 3 & 5 \\
\hline & Driver & 1 & 2 \\
\hline \multirow[t]{4}{*}{5} & \multicolumn{3}{|c|}{ Mother's Occupation } \\
\hline & Farming & 56 & 93 \\
\hline & Wage Labourer & 3 & 5 \\
\hline & Wardenship & 1 & 2 \\
\hline \multirow[t]{4}{*}{6} & \multicolumn{3}{|c|}{ Father's Education } \\
\hline & Illiterate & 57 & 95 \\
\hline & $\begin{array}{l}\text { Primary }\left(1^{\mathrm{st}}-5^{\text {th }}\right. \\
\text { standard })\end{array}$ & 2 & 3 \\
\hline & $\begin{array}{l}\text { Middle }\left(6^{\text {th }}-8^{\text {th }}\right. \\
\text { standard })\end{array}$ & 1 & 2 \\
\hline \multirow[t]{3}{*}{7} & \multicolumn{3}{|c|}{ Mother's Education } \\
\hline & Illiterate & 58 & 97 \\
\hline & Primary & 2 & 3 \\
\hline \multirow[t]{4}{*}{8} & \multicolumn{3}{|l|}{ Caste } \\
\hline & ST & 47 & 78 \\
\hline & $\mathrm{SC}$ & 6 & 10 \\
\hline & $\mathrm{BC}$ & 7 & 12 \\
\hline
\end{tabular}


Table.2 Mass media exposure of rural adolescent school dropout girls $(\mathrm{N}=60)$

\begin{tabular}{|l|l|c|c|c|c|c|c|}
\hline S.No & Mass Media & \multicolumn{3}{|c|}{ Frequency } & \multicolumn{3}{c|}{ Percentage (\%) } \\
\cline { 3 - 8 } & Exposure & Daily & Occasionally & Never & Daily & Occasionally & Never \\
\hline $\mathbf{1}$ & Radio & 0 & 0 & 0 & 0 & 0 & 0 \\
\hline $\mathbf{2}$ & Television & 32 & 8 & 20 & 53 & 13 & 33 \\
\hline $\mathbf{3}$ & Mobile & 48 & 4 & 8 & 80 & 7 & 13 \\
\hline $\mathbf{4}$ & News paper & 0 & 0 & 60 & 0 & 0 & 100 \\
\hline $\mathbf{5}$ & Internet & 0 & 0 & 60 & 0 & 0 & 100 \\
\hline
\end{tabular}

Table.3 To analyze the reasons for rural adolescent girl's school dropouts

\begin{tabular}{|c|c|c|c|}
\hline S.NO & PERSONAL ISSUE & $\mathbf{F}$ & $\%$ \\
\hline \multirow[t]{4}{*}{1} & \multicolumn{3}{|c|}{ Reasons for dropout based on personal issues } \\
\hline & Poor academic performance & 20 & 33 \\
\hline & Lack of Interest & 50 & 83 \\
\hline & Health problems & 4 & 7 \\
\hline \multirow[t]{11}{*}{2} & \multicolumn{3}{|c|}{ Respondent's peer group influence } \\
\hline & $\begin{array}{l}\text { Had friends who also dropped } \\
\text { out }\end{array}$ & 4 & 7 \\
\hline & \multicolumn{3}{|l|}{ Family Environment } \\
\hline & Poverty & 34 & 57 \\
\hline & Early Marriage & 2 & 3 \\
\hline & Lack of parental interest & 28 & 47 \\
\hline & Parent's death & 14 & 23 \\
\hline & Father's death & 6 & 10 \\
\hline & Mother's death & 12 & 20 \\
\hline & Performing household chores & 8 & 13 \\
\hline & $\begin{array}{l}\text { Undertaking agricultural } \\
\text { operations }\end{array}$ & 16 & 27 \\
\hline
\end{tabular}


Table.4 To Know the awareness and utilization of ongoing educational programs to girl

\begin{tabular}{|l|l|l|l|}
\hline S.NO & Statements & F & $\mathbf{\%}$ \\
\hline $\mathbf{1}$ & Are you aware of sarva shiksha abhiyan proramme & 0 & 0 \\
\hline $\mathbf{2}$ & $\begin{array}{l}\text { Are you aware of Rashtriya Madhyamik Shiksha Abhiyan } \\
\text { Are you aware of Girls Hostel Scheme }\end{array}$ & 0 & 0 \\
\hline $\mathbf{4}$ & $\begin{array}{l}\text { Are you aware of National Scheme of Incentives to Girls for Secondary } \\
\text { Education }\end{array}$ & 0 & 0 \\
\hline $\mathbf{5}$ & $\begin{array}{l}\text { Are you aware of Scheme for construction and running of Girls' Hostel } \\
\text { for students of secondary and higher secondary schools }\end{array}$ & 0 & 0 \\
\hline $\mathbf{6}$ & \begin{tabular}{l} 
Are you aware of National Scholarships \\
\hline
\end{tabular} & 0 & 0 \\
\hline
\end{tabular}

From table 3 it is noticed that $83 \%$ of adolescent girls dropped out from school due to 'lack of interest', 33\% dropped out due to 'poor academic performance', and $3 \%$ of them dropped out due to 'health problems.' $7 \%$ of the adolescent girls dropped out from the school due to the reason that 'Her friends also dropped out.'and57\% of adolescent girls dropped out because of 'poverty', 47\% of adolescent girls dropped out due to 'lack of parental interest', $27 \%$ of dropped out due to 'undertaking agricultural activities,' $23 \%$ of adolescent girls dropped out because of 'parental death', $20 \%$ of adolescent girls dropped out because of 'mother's death', 13\% dropped out because of 'performing household activities,' and $10 \%$ of them dropped out due to 'father's death,' and $3 \%$ dropped out due to 'early marriage.'

From the table 4 , it is very dejected to note that none of them are aware of these government programmes. Hence, an awareness campaign should be there so that the knowledge and utilization of ongoing educational programs for school dropout.

It is concluded that, though the school education department succeeded in increasing the enrolment ratio in Mahbubnagar which is the most backward district in the state, The research findings stated that that Majority of adolescent girls dropped out from school due to 'lack of interest'. When it comes awareness and utilization of ongoing educational programs to girl. None of them are aware of these government programmes. To improve the adolescent girl enrollment ratio in school the Teachers should build confidence in girls and make them to understand the importance of school education.

\section{References}

Baharulhennyei, P., Tungjanbemo, L, Limawati Aier. K and Zhimomi Islam Laskar. L. 2017. A Study on School Dropouts in Rural Niuland Block, Nagaland. An International Journal of Humanities and Social Sciences. 4 (2): 212-231.

Deepak Kumar, D., 2016. Causative Factors of School Dropouts: A Case Study of Rural Areas of Mahabubnagar District of Telangana, India. Imperial journal of interdisciplinary research. 2 (8): 655-665.

Latif, A., Choudhary AI and Hammayun, A.A. 2015. Economic Effects of Student Dropouts: A Comparative Study. Journal of Global Economics. 3 (2): 2-4. 
Ravi Prakash, Tara Beattie, Prakash Javalkar, Parinita Bhattacharjee, Satyanarayana Ramanaik, Raghavendra Thalinja, Srikanta Murthy, Calum Davey, James Blanchard, Charlotte Watts, Martine Collumbien, Stephen Moses, Lori Heise and Shajy Isac,. 2017. Correlates of school dropout and absenteeism among adolescent girls from marginalized community in north Karnataka, south India. Journal of Adolescence. 64-76.

Rev. Dr. Owusu-Boateng William,
Acheampong Frank and Oteng Agyekum-Emmanuel. 2015. The effect of school dropout on the lives of the youth in Akim Tafo community. Global Educational Research Journal. 3 (10): 347-369.

Santosh, S., Krishna. D and Anju. A. 2016. Vocational Interest of School Dropout Adolescents Girls. An International Journal of Humanities and Social Sciences - International Journal of Scientific Research. 5 (8): 272-274.

\section{How to cite this article:}

Sathwika, B. and Geetha Reddy, R. 2019. A Study on Adolescent Girl School Dropout in Mahabubnagar District of Telangana State, India. Int.J.Curr.Microbiol.App.Sci. 8(02): 474480. doi: https://doi.org/10.20546/ijcmas.2019.802.053 